\title{
Diagnosis of Cutaneous T Cell Lymphoma \\ by use of Monoclonal Antibodies Reactive with
}

\section{Tumor-associated Antigens}

\author{
Carole L. Berger, Sherie Morrison, Anthony Chu, Jennifer Patterson, \\ alison Estabrook, Shinichero Takezaki, Jacqueline Sharon, \\ Dorothy Warburton, OsCar Irigoyen, and Richard L. Edelson, \\ Departments of Dermatology, Microbiology, Human Genetics, Surgery, and \\ Medicine, College of Physicians \& Surgeons of Columbia University, \\ New York 10032
}

A B S TRACT Two murine monoclonal antibodies (BE1 and BE2), produced by using leukemic helper $T$ cells from a patient with cutaneous $T$-cell lymphoma (CTCL) as immunogens, reacted selectively with CTCL lymphocytes and some transformed cultured lymphocytes, as determined by radioimmunoassay (RIA) and indirect immunofluorescence (IIF).

BEl reacted significantly $(P \leq 0.001)$ with leukemic CTCL lymphocytes and with CTCL cells from infiltrated lymph nodes (RIA, mean $\pm S D=776 \pm 275 \mathrm{cpm}$ ),

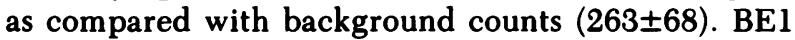
binding to normal blood mononuclear cells (RIA, mean $\pm S D=283 \pm 58 \mathrm{cpm}$ ) was indistinguishable from background. BEl also reacted with Epstein-Barr virus (EBV)-transformed B-cell lines (RIA, mean \pm SD $=794 \pm 230)$ and some long-term T-cell lines. BE1 did not react with the majority of lymphoid cell lines or tumor cell lines tested. BEl also did not react with any normal tissues screened by IIF. BEl precipitated a molecule from CTCL cells that, under reducing conditions, has two components with molecular mass of 27,200 and $25,800 \mathrm{D}$.

BE2 also reacted significantly $(P \leq 0.001)$ with CTCL cells from two of four patients (RIA, mean \pm SD $=519 \pm 113 \mathrm{cpm}$ ). The binding of BE2 to normal mononuclear cells was indistinguishable from background

This work was presented, in part, at the Annual Meeting of the Society for Investigative Dermatology, San Francisco, CA, 28 April 1981, and was reported in abstract form in 1981. Clin Res. 29: 588a.

Dr. Berger is a fellow of the Leukemia Society of America. Dr. Edelson is a recipient of the Irma T. Hirschl Award.

Received for publication 22 October 1981 and in revised form 31 August 1982.
$(309 \pm 38 \mathrm{cpm})$. BE2 also reacted with an antigen present on EBV-B-cell lines (RIA, mean \pm SD $=654 \pm 194$ ) and MOLT 3 and HUT 78 T-cell lines. BE2 reacted with an antigen expressed on a subpopulation of lymphocytes from five of eight patients with B-cell CLL studied by IIF (mean \pm SD $=18 \pm 6$ ). Other long-term $T$-cell lines and tumor cell lines studied by IIF were unreactive with BE2. BE2 did not react with any of the normal tissues studied. BE2 precipitated a molecule $(78,000 \mathrm{D})$ from CTCL cells and EBV-B cells with a single component under reducing conditions.

Immunoperoxidase-labeled $\mathrm{BE} 1$ and $\mathrm{BE} 2$ reacted with CTCL cells in frozen sections of infiltrated lymph nodes and skin. In addition, $\mathrm{BE} 1$ and $\mathrm{BE} 2$ reacted with blood lymphocytes from 16 of 21 patients whose CTCL had otherwise been considered localized to skin.

These two monoclonal antibodies react with tumor antigens associated with CTCL and appear to be useful in the diagnosis of this disorder.

\section{INTRODUCTION}

Monoclonal antibodies with specificity for $\mathrm{T}$ lymphocytes at various stages of differentiation have facilitated the characterization of human lymphocyte membrane antigens. Use of these reagents have revealed that certain leukemias are neoplastic amplifications of T-cell populations with distinctive phenotypes. For example, the malignant lymphocytes of some patients with acute lymphocytic leukemia express a phenotype similar to that found on cortical thymocytes (1). In contrast, the malignant lymphocytes from patients with cutaneous T-cell lymphoma (mycosis fungoides, Sezary syndrome) regularly have a phenotype characteristic of mature normal helper $T$ cells $(2-4)$, cor- 
relating with prior studies which indicated that $\mathrm{cu}$ taneous T-cell lymphoma (CTCL) ${ }^{1}$ cells frequently have the functional capabilities of helper $T$ cells $(5,6)$.

Although the linkage of helper T-cell phenotype and skin infiltration supports the suggestion that CTCL is a single entity, monoclonal antibodies specific for normal helper $T$ cells are not helpful in distinguishing CTCL from benign helper T-cell infiltrates. CTCL, which has an incidence approximating that of Hodgkin's disease (7), typically presents as a cutaneous disorder, subsequently disseminating widely to the viscera. The median survival from time of light microscopic diagnosis of CTCL is $5 \mathrm{yr}$ (8). Monoclonal reagents capable of identifying the skin phase of CTCL might permit diagnosis at a time when intensive therapy directed at the skin could be curative (9).

Monoclonal antibodies against tumor-associated antigens of acute lymphoblastic and chronic myelocytic leukemia cells (10), mammary tumors (11), melanoma (12), and colonic carcinoma (13) have been reported. The observation that CTCL cells could be distinguished from normal helper $T$ cells by their failure to express the phenotypic marker $3 \mathrm{Al}$ (4) raised the possibility that CTCL might also express tumor-associated antigens.

We report here the production of two monoclonal antibodies that react with human CTCL cells, but not with normal helper $T$ cells. These reagents appear to be valuable in the diagnosis of the cutaneous lesions of CTCL, as well as in recognizing histologically inapparent extracutaneous spread by the malignant cells.

\section{METHODS}

\section{Hybridoma production}

Immunization schedule. Hybridomas were produced using modifications of the methodology defined by Kohler and Milstein (14). BALB/c mice (West Seneca Farms, Buffalo, NY) were primed with $1 \times 10^{7}$ lymphocytes obtained from leukapheresis of a patient with T-cell leukemia. Previous phenotypic and functional studies revealed that the leukemic cells from this patient (M.B., lymphocyte count $\left.420 \times 10^{6} / \mathrm{ml}\right)$ were helper T lymphocytes $(98 \%$ OKT $1+$, $87 \%$ OKT $4+, 87 \%$ OKT $4+, 0 \%$ OKT $5+)(2)$. These cells were injected intraperitoneally into mice and the mice were boosted at weekly intervals for $3 \mathrm{wk}$. Sera were obtained from the retroorbital plexus of the mice, and the antibody titers were determined before fusion.

Fusion. The splenocytes were obtained by teasing the spleens until a cell suspension was formed. The cell suspen-

${ }^{1}$ Abbreviations used in this paper: CLL, chronic lymphocytic leukemia; CTCL; cutaneous T-cell lymphoma; EBV, Epstein-Barr virus; DME, Dulbecco's-modified Eagle's medium; FCS, fetal calf serum; HAT, hypoxanthine, aminopterin, thymidine; IIF, indirect immunofluorescence; PHA, phytohemagglutinin. sion was collected and washed in Iscoves-modified Dulbecco's media (IMDM, Gibco Laboratories, Grand Island Biological Co., Grand Island, NY) containing $20 \%$ fetal calf serum (FCS, Gibco Laboratories). Each hyperimmunized mouse spleen yielded at least $2 \times 10^{8}$ spleen cells.

The myeloma cell line used for fusion was 45.6TG.1.7.5 (clone 5), a variant of MPC 11 which lacks the ability to produce immunoglobulin heavy chains. The myeloma cell line was deficient in the enzyme hypoxanthine guanine phosphoribosyl transferase, and therefore grown in Dulbecco'smodified Eagle's medium (DME, Gibco Laboratories) $20 \%$ FCS containing $5 \mu \mathrm{g} / \mathrm{ml}$ thioguanine (6 amino mercaptopurine, Sigma Chemical Co., St. Louis, MO). The myeloma and spleen cells were fused in $2 \mathrm{ml}$ of $35 \%$ polyethylene glycol solution (PEG 1000, J. T. Baker Chemical Co., Phillipsburg, NJ) in DME, pH 8-8.2 (15).

Plating. $2 \mathrm{~d}$ before plating the fusion, the media was preconditioned by using normal BALB/c spleen cells as a feeder layer at a concentration of $1 \times 10^{5}$ cells $/ \mathrm{ml}(1 \mathrm{ml} /$ well in IMDM $/ 20 \%$ FCS containing $10^{-4} \mathrm{M}$ hypoxanthine (Calbiochem-Behring Corp., American Hoechst Corp., San Diego, CA), $3 \times 10^{-5} \mathrm{M}$ thymidine (Calbiochem-Behring Corp.), and $1 \times 10^{-5} \mathrm{M}$ aminopterin, (Sigma Chemical Co.) in multiwell tissue culture plates (Linbro, Flow Laboratories, Inc., Rockville, MD). The fused cells were then resuspended in hypoxanthine, aminopterin, thymidine (HAT) at $2 \times 10^{6}$ original spleen cells $/ \mathrm{ml}$ and plated $1 \mathrm{ml} /$ well on the feeder layer.

Screening. After 2 wk of incubation, hybrid clones were identifiable in all wells of the microtiter plates. Supernatants were collected and tested for reactivity by screening against CTCL lymphocytes, normal peripheral blood lymphocytes, and an Epstein-Barr virus (EBV)-transformed normal B-cell line (GM 1056, American Type Tissue Culture Collection). Screening was performed using a sensitive radioimmunoassay (RIA) system (16).

RIA. ${ }^{125}$ Iodine (Amersham Corp., Arlington Heights, IL) was attached to affinity purified rabbit anti-mouse immunoglobulin (purified by S. Morrison) using the chloramine$T$ method (16). Free ${ }^{125} \mathrm{I}$ was removed by passage over an anion exchange column containing DE 52 (Whatman Inc., Clifton, NJ), DEAE Sephadex (Pharmacia Fine Chemicals, Piscataway, NJ), and Dowex 1-X8-50 (J. T. Baker Chemical Co.) resins. The ${ }^{125} \mathrm{I}$-labeled anti-mouse antibody was adjusted before use so that a $25-\mu 1$ sample provided $30,000 \mathrm{cpm}$ in a gamma counter (Amersham Corp.). Target cells were adjusted to $10 \times 10^{6} / \mathrm{ml}$ in $0.15 \mathrm{M}$ phosphate buffer ( $\mathrm{pH} \mathrm{7.0)}$ containing $10 \%$ horse serum devoid of gamma globulin (Gibco Laboratories). A 50- $\mu$ l aliquot of the cell suspension was then added to the wells of a U-bottom plate (Dynatech Laboratories, Inc., Alexandria, VA). The plates were centrifuged ( $185 \mathrm{~g}, 6 \mathrm{~min})$ and the supernatants decanted. The cells were resuspended in $50 \mu$ l of hybridoma supernatant or purified ascitic fluid (diluted to $3.3 \mu \mathrm{g}$ protein $/ \mathrm{ml}$ ) and the plates were incubated for $60 \mathrm{~min}$ on a rotary shaker. The plates were then washed three times in buffer and $50 \mu \mathrm{l}$ of the ${ }^{125} \mathrm{I}$-labeled anti-mouse immunoglobulin reagent added. After incubation for $60 \mathrm{~min}$ on the rotary shaker at room temperature, the plates were again washed three times in buffer. The cells were resuspended in $25 \mu \mathrm{l}$ of buffer and the contents of each well swabbed out with a cotton applicator. The cotton tips of the applicators were then counted in a gamma counter. To ensure that the specificity of the binding of the monoclonal antibodies was not masked by excess antibody inhibiting the binding of the heterologous iodinated rabbit anti-mouse reagent, a titration was performed (Table I). Increasing concentrations of ${ }^{125} \mathrm{I}$-labeled rabbit anti- 
mouse were added to the monoclonal antibodies at a concentration of $3.3 \mu \mathrm{g} / \mathrm{ml}$. The binding of the heterologous ${ }^{125} \mathrm{I}$ rabbit antisera was tested at $30,000,50,000$, and 100,000 cpm in $25 \mu \mathrm{l}$ (Table I).

Cloning. Positive wells were retested after a week to determine whether the initially identified hybrids were still secreting reactive antibodies. The contents of the positive wells were then cloned by plating in agarose over a rat embryo fibroblast feeder layer (derived by S. Morrison).

\section{Characterization of the monoclonal antibodies}

To further characterize the specificity of the monoclonal antibodies obtained from ascitic fluid, the following two methods were used.

Indirect immunofluorescence (IIF). Reactivity of antibodies with lymphocytes was determined by IIF. Lymphocytes or acetone-fixed frozen tissue sections were incubated with varying dilutions of monoclonal antibodies for $30 \mathrm{~min}$ at $4^{\circ} \mathrm{C}$, and then washed three times in phosphate-buffered saline (PBS). The samples were then incubated with a Fab fluorescein-conjugated rabbit anti-mouse immunoglobulin (N. L. Cappel Laboratories Inc., Cochranville, PA) for 30 min at $4^{\circ} \mathrm{C}$ and washed again in PBS. The binding of the fluorescein-labeled reagent was detected under a Leitz epifluorescent microscope (E. Leitz, Inc., Rockleigh, NJ) or by passage of the stained cells through a cytofluorograf (FC200/ 4800A, Ortho Instruments, Westwood, MA).

Immunoperoxidase staining. The reactivity of the monoclonal antibodies with lymphocyte populations in frozen sections of tissue from both benign and tumor specimens was determined using the immunoperoxidase technique, as modified by Chu and MacDonald (17).

\section{Lymphocyte isolation}

Freshly obtained peripheral blood lymphocytes and cryopreserved specimens from patients and controls were studied. Lymphocytes were isolated by flotation of peripheral blood on Ficoll-Hypaque (18). Lymphocytes were frozen in 15\% dimethyl sulfoxide (Fisher Scientific Co., Pittsburgh, PA) in RPMI 1640 with $20 \%$ FCS and stored in liquid nitrogen until use. Suspensions of normal mononuclear cells were enriched for $T$ cells by sedimenting the E-rosette positive $\mathrm{T}$-cell population (identified by the method of Weiner et al. [19]) on Ficoll-Hypaque. Cells at the T-cell-depleted interface constituted a B-cell-enriched population.

\section{Molecular weight determination}

Cells were radioiodinated using the modification of the method of Marchalonis et al. (20) previously described by Takezaki et al. ${ }^{2}$ Following iodination cells were lysed in 0.5 $\mathrm{ml}$ of $1 \%$ Nonidet P-40 (NP-40, Gallard Schlesinger, Carle Place, New York) in isotonic buffer $(10 \mathrm{mM}$ Tris, $1.5 \mathrm{mM}$ $\mathrm{MgCl}_{2}, 0.15 \mathrm{M} \mathrm{NaCl} \mathrm{pH} \mathrm{7.3)}$ on ice. Nuclei were removed by centrifugation. Lysates were precleared of nonspecific precipitates using $10 \mu \mathrm{l}$ of rabbit anti-mouse and $3 \mathrm{ml}$ of

${ }^{2}$ Takezaki, S., S. L. Morrison, C. L. Berger, P. C. Kung, A. C. Chu, and R. L. Edelson. 1981. Biochemical characterization of differentiation antigen shared by human epidermal Langerhans cells and cortical thymocytes. Manuscript submitted for publication.
IgG Sorb (Enzyme Center, Boston, MA). For specific precipitation $10 \mu \mathrm{l}$ of BE1 or BE2 (purified on a Sephacryl S200 column $\sim 1 \mathrm{mg} / \mathrm{ml}$ ) followed by $20 \mu \mathrm{l}$ of rabbit anti-mouse IgG and $250 \mu \mathrm{l}$ of IgG Sorb was used. Precipitates were washed as previously described $(20)$, bound materials eluted by boiling in $2 \%$ sodium dodecylsulfate (SDS), and the immunoprecipitates analyzed using either $5 \% \mathrm{PO}_{4}$ or $12.5 \%$ Tris glycine polyacrylamide SDS slab gels (21). After electrophoresis, gels were fixed and stained and the position of the bands determined by autoradiography. Kodak X-0 mat film (Eastman Kodak Co., Rochester, NY) was exposed at $-70^{\circ} \mathrm{C}$ with an intensifying screen.

\section{Statistical evaluation}

Evaluation of the results for statistical significance was performed by use of the standard Student's $t$ test (22).

\section{RESULTS}

Approximately 2,000 hydridomas were screened: 43 produced antibodies reactive with both $\mathrm{T}$ and $\mathrm{B}$ lymphocytes; 4 reacted only with $T$ cells; and 3 produced antibodies selectively reactive with leukemic lymphocytes from CTCL patients but not with normal lymphocytes.

Detection of monoclonal antibodies reactive with CTCL lymphocytes. Initial screening of the products of the fusion detected three monoclonal antibodies reactive by RIA with the immunizing CTCL lymphocytes but unreactive with lymphocytes from normal controls. Repeated RIA analysis of the supernatants of the original wells and of isolated subclones consistently revealed reactivity with CTCL lymphocytes, absence of significant binding to normal $\mathrm{T}$ and $\mathrm{B}$ lymphocytes and strong binding to an EBV-B-cell line (Tables I and II). Increasing concentrations of the heterologous ${ }^{125} \mathrm{I}-$ labeled rabbit anti-mouse reagent showed enhanced binding of BE1 and BE2 to CTCL lymphocytes and EBV-B-cell lines. However, even 100,000 cpm of the rabbit anti-mouse antibody did not bind significantly to normal peripheral blood lymphocytes incubated with BE1 or BE2 (Table I).

Two of these antibodies (BE1 and BE2) were strongly reactive with CTCL cells and were selected for further study. The third antibody was not studied further since its reactivity with CTCL cells was relatively weak. In addition to the EBV-B-cell line, both monoclonal antibodies were tested against lymphocytes obtained from patients with B-cell chronic lymphocytic leukemia (CLL) (Table III). Cells from five of eight patients with B-cell CLL, evaluated by IIF, reacted with $\mathrm{BE} 2$ (mean $=18 \pm 6$ ). Malignant $B$ cells from none of these CLL patients were reactive with BE1 (Table III).

Neoplastic cells and cell lines studied with BE 1 and $B E 2$. To determine the range of expression of the antigens detected by BE1 and BE2, cells from patients 
TABLE I

Titration of Iodinated Rabbit Anti-Mouse Reagent

\begin{tabular}{|c|c|c|c|c|c|c|c|c|}
\hline \multirow[b]{2}{*}{ Sample } & \multicolumn{2}{|c|}{${ }^{125} \mathrm{I}-30,000 \mathrm{cpm}^{\circ}$} & \multicolumn{2}{|c|}{${ }^{125} \mathrm{I}-50,000 \mathrm{cpm}$} & \multicolumn{2}{|c|}{${ }^{125} \mathrm{l}-100,000 \mathrm{cpm}$} & \multicolumn{2}{|c|}{ IIF $t \%+$ cells } \\
\hline & BEI & BE2 & BEl & BE2 & BEl & BE2 & BEl & BE2 \\
\hline & \multicolumn{8}{|c|}{ mean $\pm S D \$$} \\
\hline CTCL patient M.H. & $98 \pm 58$ & $724 \pm 171$ & $0 \pm 52$ & $520 \pm 61$ & $383 \pm 171$ & $1,219 \pm 180$ & $0 \pm 2$ & $51 \pm 8$ \\
\hline CTCL patient J.O. & $511 \pm 218$ & $0 \pm 15$ & $958 \pm 289$ & $0 \pm 21$ & $2,340 \pm 472$ & $0 \pm 55$ & ND & ND \\
\hline Normal MNL & $54 \pm 66$ & $68 \pm 101$ & $108 \pm 44$ & $43 \pm 173$ & $0 \pm 139$ & $35 \pm 229$ & $0 \pm 2$ & $2 \pm 2$ \\
\hline EBV-B cells & $884 \pm 260$ & $1,027 \pm 269$ & $1,503 \pm 512$ & $1,714 \pm 456$ & $3,184 \pm 836$ & $4,013 \pm 1036$ & $17 \pm 10$ & $77 \pm 14$ \\
\hline
\end{tabular}

- Rabbit anti-mouse antibody adjusted to $30,000,50,000,100,000 \mathrm{cpm}$ in $20 \lambda$.

$\downarrow$ IIF determined by passage of 10,000 cells through cytofluorograph $(n=11)$.

$\$$ Net binding obtained after subtraction of binding of nonspecific ascites fluid of same isotype and protein content to cell population ( $n=8$ duplicate samples/specimen).

ND, not done; MNL, mononuclear leukocytes.

with leukemic and nonleukemic CTCL were studied by RIA (Table IV). Significant binding of BEl ( $P$ $\leq 0.001$ ) was found in both peripheral blood and lymph node specimens from four CTCL patients. BE2 reacted with lymphocytes from one patient with leukemic disease and was also detected by RIA on lymphocytes from an effaced lymph node of one patient with nonleukemic CTCL.

In addition, lymphocytic infiltrates in lymph nodes and skin biopsies from three patients with advanced CTCL reacted with BE1 and BE2 in situ by the immunoperoxidase method. In Fig. la, a CTCL lymph node with effacement of normal architecture by malignant $T$ cells showed strong reactivity with BEl by immunoperoxidase staining. Normal lymph node (Fig.

TABLE II

Reactivity of Monoclonal Antibodies BEl and BE2 (RIA)

\begin{tabular}{lccc}
\hline \multirow{2}{*}{ Antibody } & $\begin{array}{c}\text { CTCL. } \\
\text { lymphocytes }\end{array}$ & MNL & EBV-B cells \\
\hline & & mean \pm SD & \\
BE1 & & $271 \pm 49$ & $794 \pm 230$ \\
& $1,196 \pm 303$ & $n=9$ \\
& $n=26 \downarrow$ & $n=16$ & $n \leq 0.001$ \\
BE2 & $P \leq 0.001 \S$ & & $P \leq 54 \pm 194$ \\
& $599 \pm 119$ & $294 \pm 35$ & 65010 \\
& $n=24$ & $n=10$ & $n=10$ \\
Nonimmune mouse & $P \leq 0.001$ & & $P \leq 0.001$ \\
serum & $263 \pm 68$ & $205 \pm 72$ & $112 \pm 67$ \\
& $n=26$ & $n=16$ & $n=12$ \\
\hline
\end{tabular}

- Data represent mean \pm SD.

$\downarrow n$, number of samples studied.

$\S P$ values were calculated by comparison of the binding of the monoclonal antibodies to neoplastic cells vs. the binding to normal mononuclear cells. MNL, mononuclear leukocytes. 1b), noninvolved epidermis, and thymus sections were unreactive with BE1 and BE2 by immunoperoxidase staining.

Transformed cell lines derived from T-cell leukemias and null-cell leukemias, as well as EBV-B-cell lines, were studied by both RIA and IIF to determine the distribution of the antigens recognized by $\mathrm{BE} 1$ and BE2. EBV-transformed B-cell lines showed significant binding of BE1 and BE2 $(P \leq 0.001$, Table II) as determined by RIA. MOLT 3 and HUT 78, a CTCL line, were the only tested long-term $\mathrm{T}$-cell lines that reacted with BE2 while BE1 reacted with HUT 78, HUT 102, and DND 1056 (Table V). IIF studies demonstrated that BE1 and BE2 do not react with JM, CM, CEM, HPB-ALL, or a null-cell all line. In addition, tumor cell lines were unreactive with BE1 or BE2 (Table VI). These negative tumor lines included a melanoma cell line propagated in nude mice, two breast cancer cell lines, a colon carcinoma cell line, and promyelocytic, myelocytic, and erythroid cell lines.

TABLE III

Reactivity (by IIF ${ }^{\circ}$ ) of Peripheral Blood Lymphocytes from Eight Patients with B-Cell CLL with BE1 and BE2

\begin{tabular}{lccc}
\hline \multicolumn{1}{c}{ Specimen } & BE1 & BE2 & Ascites \\
\hline $\begin{array}{l}\text { mean } \pm S D \\
\text { Mean of five patients with } \\
\quad 10 \% \text { reactivity with one }\end{array}$ & & & \\
$\quad \begin{array}{l}\text { or both antibodies } \\
\text { Mean of three patients with }\end{array}$ & $6 \pm 4$ & $18 \pm 6$ & $5 \pm 5$ \\
$\quad$ & & & \\
$\quad \begin{array}{l}\text { or both antibodies } \\
\text { Control }\end{array}$ & $4 \pm 5$ & $6 \pm 1$ & $3 \pm 2$ \\
\hline
\end{tabular}

- IIF was evaluated by cytofluorographic analysis and fluorescence microscopy. Results are expressed as percent reactive cells. 
TABLE IV

Expression of Cell Surface Antigens (by RIA) on CTCL Lymphocytes

\begin{tabular}{llcc}
\hline Patient & \multicolumn{1}{c}{ Dx/Specimen } & BE1 & \multicolumn{2}{c}{ BE2 } \\
\hline & & \multicolumn{2}{c}{ mean $\pm S D$} \\
M.B. & Leukemic CTCL/PB & $1,158 \pm 364^{\circ}$ & $599 \pm 119^{\circ}$ \\
E.M. & Leukemic CTCL/PB & $793 \pm 139^{\circ}$ & $307 \pm 32 \ddagger$ \\
J.M. & CTCL/effaced LN & $595 \pm 145^{\circ}$ & $322 \pm 72 \downarrow$ \\
C.O. & CTCL/effaced LN & $588 \pm 112^{\circ}$ & $438 \pm 58^{\circ}$
\end{tabular}

Normal

controls

$(n=26)$

PB

$283 \pm 58$

$309 \pm 38$

- Significant binding $(P \leq 0.001)$ of monoclonal antibody compared with binding to control lymphocytes.

\ Nonsignificant binding.

Dx, diagnosis; PB, peripheral blood; LN, lymph node.

Nonreactivity of BE1 and BE2 with normal tissues. Frozen sections of normal tissues were screened for reactivity with BEl and BE2. As presented in Table VII, there was no staining detected in any of the normal tissues screened.

Studies on patients with primary CTCL. Peripheral blood specimens from 21 patients with clinically evident CTCL, without histologically apparent lymph node involvement, were tested for expression of the antigens detected by BE1 and BE2. 10 of these patients were studied in a double-blind fashion, and the codes were broken after completion of the study with karyotypes, and histopathology as reported in Table VIII.

These CTCL patients were divided into three groups. Group I (Table VIII) consisted of patients with evidence of disseminated disease on lymph node biopsy and karyotypic analysis. Five patients were placed into group I, four on the basis of lymph node biopsy and one because of an overt leukemia. Two of these patients (J.A. and W.S.) had received prior chemotherapy last administered 1 mo before testing of their cells. Substantial testing of normal peripheral blood lymphocytes revealed minimal reactivity with BEl (mean $=2 \pm 3$ ) and BE2 (mean $=3 \pm 2$ ). This was not different from the binding of nonspecific ascites to normal control lymphocytes (mean $=4 \pm 3$ ). Therefore, a value of $10 \%$ reactivity was selected as the level of significant reactivity with $\mathrm{BE} 1$ or $\mathrm{BE} 2$ since this value was greater than 2 SD above background. All of the patients in group I had substantial circulating populations of mononuclear cells reactive with BE1 $(\geq 19 \%)$. In addition, in four of five patients $>10 \%$ of the blood mononuclear cell population carried an antigen reactive with BE2. All patients with proven extracutaneous disease had circulating cells reactive with one or both monoclonal antibodies.

Eight patients were placed in group II (Table VIII) on the basis of widespread erythroderma, since erythrodermic patients have been shown in other studies to have morphologically abnormal circulating cells $(23,24)$. Lymph node biopsies in this group were read as either normal, involved, or dermatopathic lymphadenitis. One of these eight patients (A.D.) was found to have $34 \%$ of his circulating mononuclear cells carrying an antigen detected by BEl; five of eight patients had circulating cells reactive with the monoclonal antibody BE2. Therefore, $63 \%$ of the erythrodermic patients studied were reactive in varying degrees with either or both BE1 or BE2. It should be noted that three patients with very advanced disease did not react with either BE1 or BE2.

Eight patients were placed in group III, which consisted of patients without evidence of disseminated disease (Table VIII). Six of eight patients had substantial numbers of circulating cells reactive with BEl or BE2 $(\geq 13 \%)$. Less than $11 \%$ of the circulating mononuclear cells from two of the eight patients reacted with BEl and BE2.

In summary, 16 of 21 patients $(76 \%)$ with CTCL could be diagnosed as having disseminated disease on the basis of substantial circulating peripheral blood cells reactive with the monoclonal antibodies BEl or BE2. 6 of these 21 patients $(28 \%)$ were confirmed to have extracutaneous disease on the basis of lymph node biopsy or karyotype analysis. 10 patients $(48 \%)$ were suspected of having extracutaneous disease solely on the basis of reactivity with $\mathrm{BE} 1$ and $\mathrm{BE} 2,5$ patients (24\%) were considered nonreactive with BEl and BE2. Three of these patients had evidence of disease dissemination but were nonreactive with BE1 and BE2. One of these pateints died shortly after testing of disseminated CTCL. These findings suggest that patients with aggressive endstage disease may have neoplastic lymphocyte populations that do not carry the antigens recognized by BEl or BE2.

In contrast, patients with widespread psoriasis and normal controls were studied in double-blind tests and shown to be nonreactive with BEl and BE2 (when compared with the binding of ascites fluid from a mouse injected with myeloma cells producing irrelevant immunoglobulin of the $\operatorname{IgG}_{1}$ or $\operatorname{IgG}_{2 \mathrm{a}}$ subclass (Table IX).

Nonexpression of the antigens recognized by $B E 1$ and BE2 on phytohemagglutinin blasts and purified $B$ cells. The expression of BE1 and BE2 was studied on proliferating mononuclear cells induced to divide by $72 \mathrm{~h}$ incubation with the mitogen PHA. No reactivity was detected with either monoclonal antibody (Table X).

Purified normal B cells were obtained by E-rosette depletion and stained with $\mathrm{BE} 1$ and $\mathrm{BE} 2$. No reactivity was seen with either monoclonal antibody (Table X). 

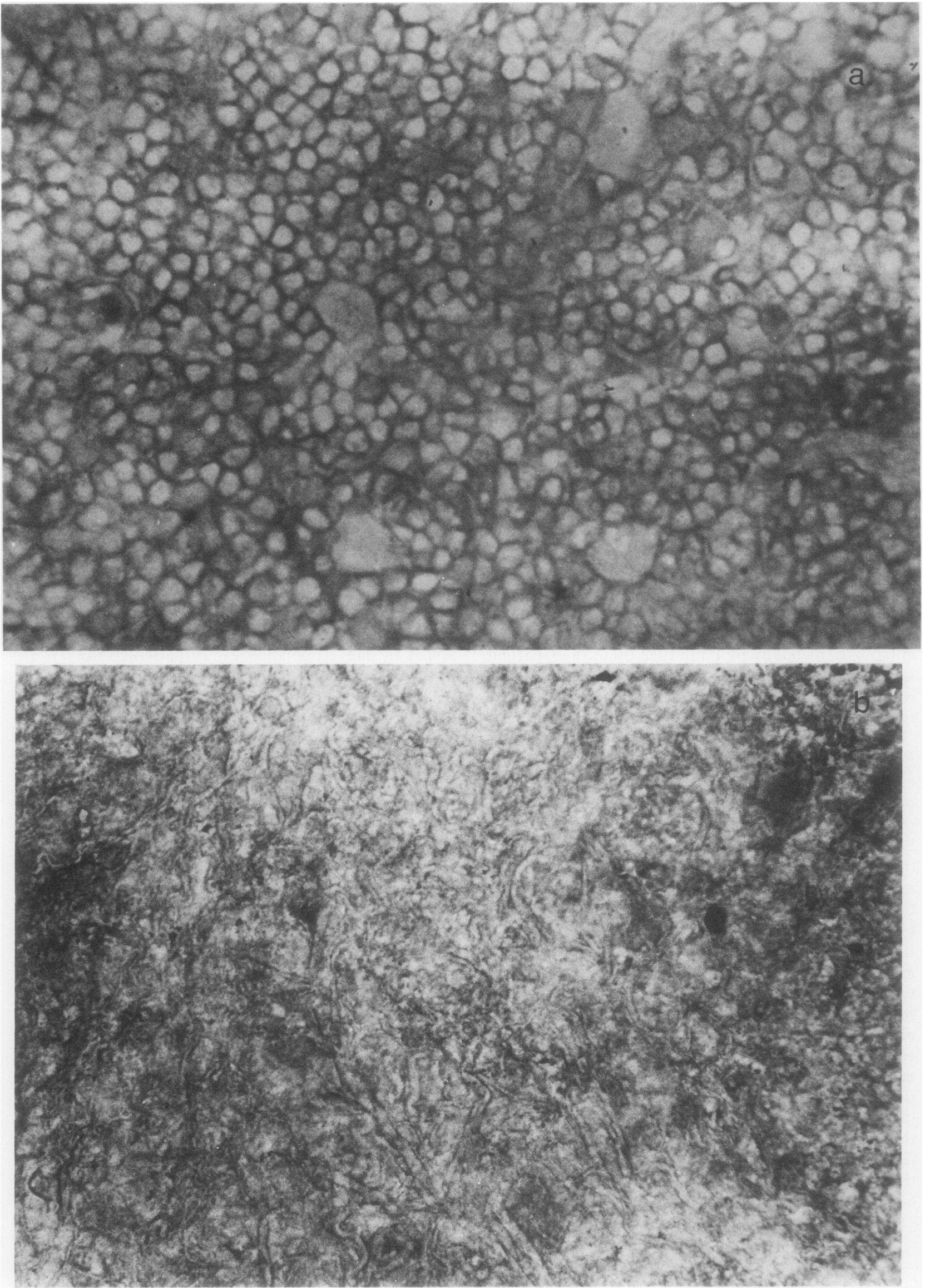
TABLE V

Binding of BE1 and BE2 to Lymphoid Cell Lines IIF \% + Cells

\begin{tabular}{llrrr}
\hline \multicolumn{1}{c}{ Cell line } & \multicolumn{1}{c}{ Description } & BE1 & BE2 & Ascites \\
\hline & & & $\%$ & \\
HUT 78 & CTCL T-cell line & 15 & 56 & Neg \\
HUT 102 & CTCL T-cell line & 10 & 0 & Neg \\
DND-1056 & T-cell ALL & 10 & 2 & Neg \\
JM & T-cell ALL & Neg & Neg & Neg \\
CM & T-cell ALL & Neg & Neg & Neg \\
CEM & T-cell ALL & Neg & Neg & Neg \\
HPB-ALL & T-cell ALL & Neg & Neg & Neg \\
MOLT 3 & T-cell ALL & Neg & Pos! & Neg \\
Null cell ALL & Null cell line & Neg & Neg & Neg \\
GM1056 & EBV-B-cell line & 17 & 77 & Neg \\
\hline
\end{tabular}

- ALL, acute lymphoblastic leukemia.

† Determined by RIA.

Neg, negative; Pos, positive.

Molecular mass of the antigens detected by BE1 and BE2. Ouchterlony immunodiffusion studies determined that BEl had a heavy chain of $\gamma 2 \mathrm{a}$ isotype and BE2 of a $\gamma 1$ isotype.

Immune precipitation studies revealed that BEl detects an antigen on CTCL cells with a molecular mass of $\sim 50,000 \mathrm{D}$. Under reducing conditions this molecule has two chains with molecular mass of 27,200 and 25,800 D (Fig. 2a). An additional small molecular mass component of $12,000 \mathrm{D}$ was also present and may represent $\beta_{2}$-microglobulin. BE2 precipitated a molecule from both CTCL cells and EBV-B cells that has a single chain with a molecular mass of $78,000 \mathrm{D}$ (Fig. 2b).

In one case the EBV-B-cell line was precipitated with the monoclonal antibody BE2 (Fig. 2b). Preclearing of this gel with $\mathrm{BE} 1$ did not remove any of the antigens reactive with $\mathrm{BE} 2$.

\section{DISCUSSION}

CTCL is a malignancy of epidermotropic helper T cells. Early in the course of CTCL, neoplastic T cells localize in the skin and frequently form focal intraepidermal collections termed Pautrier microabscesses (9). As the disease progresses, the predominant malignant $\mathrm{T}$-cell subclones demonstrate progressively less
TABLE VI

Binding of BE1 and BE2 to Tumor Cell Lines IIF \% + Cells

\begin{tabular}{lllll}
\hline \multicolumn{1}{c}{ Cell line } & \multicolumn{1}{c}{ Description } & BE1 & BE2 & Ascites \\
\hline Melanoma & Tumor in nude mice & Neg & Neg & Neg \\
MB231 & Breast CA cell line & Neg & Neg & Neg \\
MCF 7 & Breast CA cell line & Neg & Neg & Neg \\
WIDR & Colon cell line & Neg & Neg & Neg \\
HL60 & Promyelocytic cell line & Neg & Neg & Neg \\
K562 & Erythroid cell line & Neg & Neg & Neg \\
AML & AML cell line & Neg & Neg & Neg \\
\hline
\end{tabular}

AML, acute myelocytic leukemia; Neg, negative; Pos, positive; CA, carcinoma.

affinity for the epidermis and a parallel propensity to disseminate to internal viscera. The loss of epidermotropism increases the difficulty of diagnosis, since the cutaneous pathology becomes less distinctive.

Early diagnosis of CTCL is of great importance, since it appears that initially CTCL may be limited to the skin, and therapy aimed at that organ may be efficacious (9). Once the malignant cells disseminate to viscera, systemic therapy is required.

Karyotypic evidence has suggested that CTCL is a monoclonally derived malignancy (25). Those findings imply that two noncontiguous epidermal plaques must arise by hematogenous dissemination of the neoplastic

TABLE VII

Screening of Normal Tissues (by IIF) with BE1 and BE2

\begin{tabular}{llll}
\hline \multicolumn{1}{c}{ Specimen } & BEI & BE2 & Ascites \\
\hline Thyroid & Neg & Neg & Neg \\
Skin & Neg & Neg & Neg \\
Breast & Neg & Neg & Neg \\
Thymus & Neg & Neg & Neg \\
Colon & Neg & Neg & Neg \\
Liver & Neg & Neg & Neg \\
Kidney & Neg & Neg & Neg \\
Lung & Neg & Neg & Neg \\
Heart & Neg & Neg & Neg \\
Brain & Neg & Neg & Neg \\
Lymph node & Neg & Neg & Neg \\
Control CTCL lymph node & Pos & Pos & Neg \\
\hline
\end{tabular}

Neg, negative; Pos, positive.

FIGURE 1 (a) Immunoperoxidase staining of a frozen section of an effaced lymph node from a patient with CTCL. Neoplastic lymphocytes are reactive with the monoclonal antibody BEl, ( $1: 5$ dilution) as shown by the dark precipitate outlining the cells. Original magnification $\times 400$. (b) Immunoperoxidase staining of a frozen section of a normal lymph node with the monoclonal antibody BEl (1:5 dilution) showing diffuse nonspecific background staining. Original magnification $\times 400$. 
TABLE VIII

Reactivity of BE1 and BE2 with Peripheral Blood Mononuclear Cells in Patients with Early CTCL

\begin{tabular}{|c|c|c|c|c|c|c|c|c|}
\hline Patient & $\begin{array}{c}\text { Lymph } \\
\text { node } \\
\text { involvement }\end{array}$ & $\begin{array}{c}\text { Overt } \\
\text { leukemia }\end{array}$ & Skin involvement & Epidermal histopathology & Therapy & Karyotype & BEl & BE2・ \\
\hline \multicolumn{9}{|c|}{ Group I: Patients with evidence of extracutaneous disease } \\
\hline I.S. & + & - & Erythrodermic & Nonepidermotropic & Electron beam & $\begin{array}{l}\text { Peripheral blood } \\
\text { abnormal }\end{array}$ & 36 & 13 \\
\hline J.A. & + & - & $\begin{array}{l}\text { Erythrodermic } \\
\text { plaques }\end{array}$ & Epidermotropic $\S$ & Chemotherapy" & $\begin{array}{l}\text { Peripheralा blood } \\
\text { abnormal? }\end{array}$ & 19 & 15 \\
\hline W.S. & + & - & $\begin{array}{l}\text { Tumors/ } \\
\text { Disseminated } \\
\text { papules }\end{array}$ & Nonepidermotropic & Chemotherapy & ND & 24 & 12 \\
\hline R.N. & + & - & Erythrodermic & ND & $\begin{array}{l}\text { Nitrogen } \\
\text { mustard }\end{array}$ & $\begin{array}{l}\text { Lymph node } \\
\text { abnormal }\end{array}$ & 52 & 11 \\
\hline M.S. & ND & + & Erythrodermic & Epidermotropic & $\begin{array}{l}\text { Nitrogen } \\
\text { mustard }\end{array}$ & ND & 26 & 7 \\
\hline \multicolumn{9}{|c|}{ Group II: Patients with generalized erythroderma } \\
\hline C.R. & - & - & Erythrodermic & Epidermotropic & None & ND & 1 & 28 \\
\hline A.D. & DLN & - & Erythrodermic & Epidermotropic & $\begin{array}{l}\text { PUVA } \\
\text { Leukapheresis }\end{array}$ & $\begin{array}{l}\text { Peripheral blood } \\
\text { normal }\end{array}$ & 34 & 12 \\
\hline E.B. & DLN & - & $\begin{array}{l}\text { Erythrodermic } \\
\text { plaques }\end{array}$ & Epidermotropic & None & ND & 5 & 25 \\
\hline M.C. & - & - & Erythrodermic & Nonepidermotropic & None & $\begin{array}{l}\text { Peripheral blood } \\
\text { normal }\end{array}$ & 9 & 17 \\
\hline S.S. & + & + & Erythrodermic & Epidermotropic & $\begin{array}{l}\text { Leukapheresis } \\
\text { Cytoxan" }\end{array}$ & ND & 0 & 2 \\
\hline H.G. & + & + & Erythrodermic & Epidermotropic & None & ND & 0 & 6 \\
\hline M.M. & + & - & Erythrodermic & Nonepidermotropic & None & $\begin{array}{l}\text { Peripheral blood } \\
\text { normal }\end{array}$ & 0 & 1 \\
\hline M.H. & + & + & Erythrodermic & Nonepidermotropic & None & ND & 1 & 53 \\
\hline \multicolumn{9}{|c|}{ Group III: Patients without clinical evidence of extracutaneous disease } \\
\hline C.P.-V. & - & - & Plaques $\ddagger$ & Epidermotropic & None & ND & 56 & 14 \\
\hline G.K. & - & - & Plaques $\downarrow$ & Epidermotropic & None & ND & 35 & 3 \\
\hline A.J. & ND & - & Plaques & Epidermotropic & None & ND & 10 & 7 \\
\hline B.C. & DLN & - & Plaques & ND & None & $\begin{array}{l}\text { Peripheral blood } \\
\text { normal }\end{array}$ & 26 & 4 \\
\hline A.R. & DLN & - & Plaques & Epidermotropic & None & ND & 13 & 15 \\
\hline M.G. & - & - & Plaques/tumors & Epidermotropic & None & ND & 27 & 46 \\
\hline S.C. & DLN & - & Plaques & Epidermotropic & None & ND & 3 & 3 \\
\hline B.P. & DLN & - & Plaques $\ddagger$ & Epidermotropic & None & ND & 28 & 9 \\
\hline
\end{tabular}

- Percent reactive mononuclear cells/IIF.

\ Mononuclear cell infiltrate predominantly in dermis. An uninvolved Grenz zone of papillary dermis is present between upper edge of dense infiltrate and epidermis. If mononuclear cell infiltration of the epidermis occurs it is limited and characterized by pockets of single cells.

§ Epidermotropic: Mononuclear cell infiltrate abuts epidermis and apparently extends directly from epidermis to dermis. Overt infiltration of the epidermis and Pautrier microabscesses are present.

" Patients on chemotherapy had received no treatment at least 1 mo before testing.

IT ? Abnormal: Missing Y chromosome not clearly linked to malignancy.

- Patients with $<15 \%$ of their body surface involved with 2-4 noncontiguous plaques.

DLN, dermatopathic lymphadenitis; ND, not done; PUVA, psoralen and UV-A therapy. 
TABLE IX

Patients with Psoriasis and Normal Control Peripheral Blood Mononuclear Cells Studied with BE1 and BE2

(IIF)

\begin{tabular}{lccc}
\hline \multicolumn{1}{c}{ Subjects } & BE1 & BE2 & Ascites \\
\hline & & mean \pm SD & \\
Psoriatics $(n=9)$ & $2 \pm 1.5^{\bullet}$ & $7 \pm 4.0$ & ND \\
Normal controls $(n=14)$ & $2 \pm 2.9$ & $3 \pm 2.3$ & $4.1 \pm 3$ \\
\hline
\end{tabular}

- Percent positive cells.

ND, not done.

cells. Bunn et al. (23) identified extracutaneous lymphoma in $88 \%$ of the patients studied, through use of special studies including $\mathrm{T}$-cell morphology, electron microscopy, and cytogenetics.

The studies reported here suggest that early diagnosis of hematogenous spread of CTCL may be substantially aided by the use of two monoclonal antibodies BE1 and BE2. Whereas karyotypic and morphologic studies have an important place in the diagnosis of CTCL, they also have significant limitations. Karyotypic analysis requires that the malignant cells be able to respond to mitogens, a functional capacity frequently lost early in the ontogeny of CTCL $(6,26)$, and chromosome breaks deletions, duplications, and rearrangements are probably late sequelae of the aberrant mitotic process in CTCL. Furthermore, the morphologic abnormalities associated with CTCL are not specific for the disorder and have been noted in normal mitogen-activated lymphocytes, as well as in benign skin infiltrates (27).

The possibility that CTCL lymphocytes have lost normal T-lymphocyte antigens and might express an altered cell surface phenotype has been suggested by two studies. Haynes et al. (4) have shown that an antigen expressed on normal $T$ lymphocytes, recognized by the monoclonal antibody $3 \mathrm{Al}$, is generally not present on CTCL lymphocytes. Similarly, studies per- formed in our laboratory (2) have revealed that lymphocytes from some CTCL patients no longer carry an antigen recognized by the pan-T-cell monoclonal antibody OKT1, while still expressing a mature helper T-cell phenotype (OKT3+, OKT4+, OKT5-).

These studies have shown that at least two different tumor-associated antigens recognized by the monoclonal antibodies BE1 and BE2 occur on CTCL lymphocytes. The presence of tumor-associated antigens on the surface of neoplastic cells in various leukemias (T-cell acute lymphocytic leukemia, B-cell acute lymphocytic, non-T non-B-cell acute lymphocytic leukemia, chronic myelocytic leukemia) was initially suggested by studies involving heteroantisera $(28,29)$. Due to weak reactivity of heterologous antisera and the incomplete removal of nonspecific antibodies by even exhaustive absorptions with transformed cell lines, tumor-associated antigens have been difficult to isolate and characterize. The introduction of hybridoma technology for the production of monoclonal antibodies has confirmed the existence of tumor-associated antigens and allowed the detection of weakly immunogenic molecules.

The presence of tumor-related molecules on CTCL cells has been detected by two monoclonal antibodies, BE1 and BE2 which identify two separate antigenic determinants. BEl has reacted with lymphocytes from the majority of CTCL patients as well as with an EBVB-cell line. Peripheral blood lymphocytes from normal controls, and patients with benign skin disease, do not express significant quantities of BE1. Similarly, BE2 has been shown to be present on lymphocytes from some CTCL patients and on cells from transformed $\mathrm{T}$ - and B-cell lines. Normal lymphocytes, and benign dermatoses do not show detectable reactivity with BE2.

The antigens recognized by $\mathrm{BE} 1$ and $\mathrm{BE} 2$ are clearly not restricted in expression to CTCL lymphocytes, but rather are present on a variety of transformed cell types. The absence of expression of these tumor-associated molecules on normal lymphocytes permits the

TABLE X

Absence of Expression of BE1 and BE2 on Normal B Cells and PHA-stimulated Blasts

(IIF)

\begin{tabular}{lcccr}
\hline Specimen & BE1 & BE2 & Ascites & OKT3 \\
\hline & \multicolumn{4}{c}{ mean $\pm S D$} \\
$\begin{array}{l}\text { Mononuclear cells cultured } \\
\text { in media for 3 d }\end{array}$ & $0.5 \pm 0.6$ & $2 \pm 0.8$ & $1 \pm 1$ & $64 \pm 8$ \\
$\begin{array}{l}\text { Mononuclear cells stimulated } \\
\quad \text { with PHA for 3 d }\end{array}$ & $2 \pm 2$ & $3 \pm 1$ & $2 \pm 2$ & $43 \pm 7$ \\
$\begin{array}{l}\text { Purified B cells } \\
\text { P }\end{array}$ & $0.3 \pm 0.5$ & $0.8 \pm 1.5$ & $0 \pm 0$ & $6 \pm 6$ \\
\hline
\end{tabular}




\section{CTCL Lymphocytes}

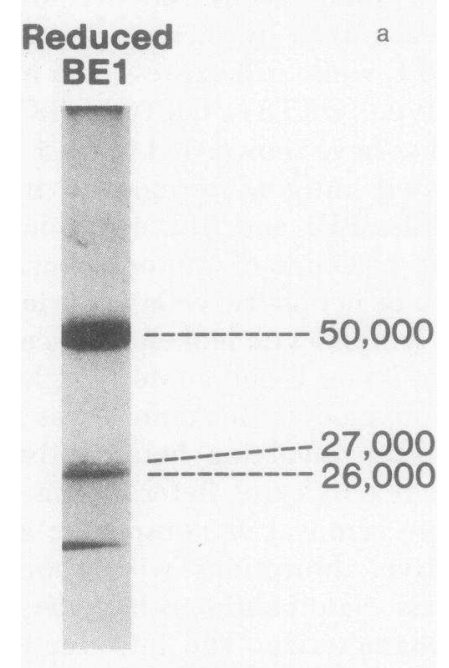

EBV-B-Cell Line

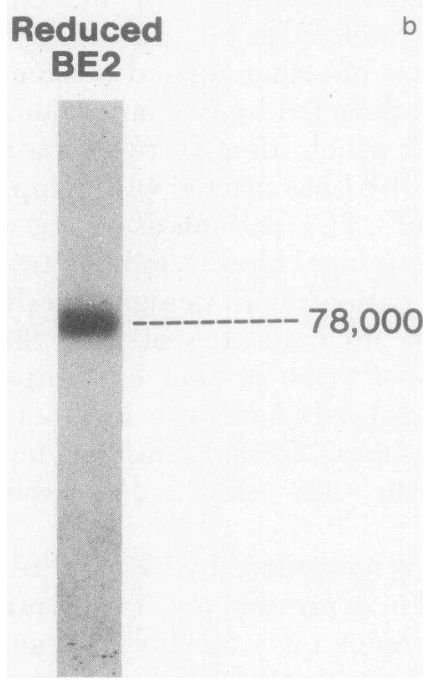

Figure 2 (a) Immune precipitation of the antigen recognized by the monoclonal antibody $\mathrm{BE} 1$ from lymphocytes of a patient with CTCL. The 50,000-D band has two components under reducing conditions of $\sim 27,000$ and 26,000 D. A smaller molecule at $12,000 \mathrm{D}$ may represent $\beta_{2}$-microglobulin. (b) Immune precipitation of the antigen recognized by the monoclonal antibody BE2 from an EBVtransformed B-cell line (GM 1056). The 78,000-D molecule has one component under reducing conditions.

use of BE1 and BE2 for identification of small numbers of neoplastic cells. Extensive screening of normal tissues and nonlymphoid tumor cell lines demonstrated that antigens recognized by $\mathrm{BE} 1$ and $\mathrm{BE} 2$ are apparently restricted to neoplastic cells of a lymphoid origin. The studies performed on lymphocytes from patients with B-cell CLL further suggest that only a small population of transformed cells may express the antigens recognized by $\mathrm{BE} 2$. The isolation and characterization of this population may allow investigation of the functional role of the antigen detected by BE2.

Several lines of evidence indicate that BEl and BE2 recognize distinct membrane antigens. The two antibodies react with different cells and to different extents with blood cells from individual patients. In addition, immune precipitation revealed that the antigen reactive with BE1 had an apparent molecular mass of $53,000 \mathrm{D}$ and has two subunits linked by disulfide bonds with respective apparent molecular mass of 27,200 and $25,800 \mathrm{D}$. In contrast, BE2 precipitated a molecule with a single component and a molecular mass of $78,000 \mathrm{D}$. In one experiment, preclearing of a gel with BEl did not affect the antigen immune precipitated by the monoclonal antibody $\mathrm{BE} 2$ from an EBV-B-cell line. The molecular mass of the antigenic determinants recognized by these two monoclonal antibodies are different from previously reported tumorassociated molecules.

The results from studies of peripheral blood specimens from patients with early CTCL suggest that BEl and BE2 may facilitate the diagnosis of this disorder. The ability to rapidly identify circulating abnormal cells in patients with disease otherwise considered limited to the epidermis would allow the earlier institution of systemic therapy.

The potential of monoclonal antibodies in the treatment of CTCL is intriguing. Previous studies using heterologous antithymocyte globulin (30) and monoclonal anti-normal $\mathrm{T}$ cell antibodies (31) in the treatment of CTCL patients produced partial clinical responses. However, the studies performed with the monoclonal antibodies demonstrated that malignant cells may modulate their surface antigens and escape destruction from subsequent antibody therapy (32). Miller et al. (33) have elegantly demonstrated that monoclonal antiidiotypic antibodies can be used in the therapy of a B-cell CLL patient. Antibodies such as BEl and BE2 that may be specific for malignant cells and nonreactive with normal cells may provide efficacious reagents for the treatment of CTCL. Alternatively, combinations of several complementary monoclonal antibodies with cell cycle-active chemotherapeutic agents may be effective in the treatment of CTCL.

\section{ACKNOWLEDGMENTS}

We wish to acknowledge the excellent secretarial assistance of Mrs. Alice Bender, Ms. Denise Ford, and Ms. Violet Aponte.

This work was supported in part by National Institutes of Health grants CA20499, 1 POL AGO2307, CA 13696, and RR 0065 . 


\section{REFERENCES}

1. Reinherz, E. L., P. C. Kung, G. Goldstein, R. H. Levey, and S. F. Schlossman. 1980. Discrete stages of human intrathymic differentiation: analysis of normal thymocytes and leukemic lymphoblasts of T-cell lineage. Proc. Natl. Acad. Sci. USA. 77: 1588-1592.

2. Kung, P. C., C. L. Berger, G. Goldstein, P. LoGerfo, and R. L. Edelson. 1980. Cutaneous T-cell lymphoma: characterization by monoclonal antibodies. Blood. 57: 261266.

3. Boumsell, L., A. Bernard, E. L. Reinherz, L. M. Nadler, J. Ritz, H. Coppin, Y. Richard, L. Dubertret, F. Valensi, L. Degos, J. Lemerle, G. Flandrin, J. Dausset, and S. F. Schlossman. 1981. Surface antigens on malignant Sezary and $\mathrm{T}$ cell all correspond to those of mature $\mathrm{T}$ cells. Blood. 57: 526-530.

4. Haynes, B. F., R. S. Metzger, J. D. Minna, and P. A. Bunn, 1981. Phenotypic characterization of cutaneous T-cell lymphoma. Use of monoclonal antibodies to compare with other malignant T cells. N. Engl. J. Med. 304: 1319-1323.

5. Broder, S., R. L. Edelson, M. A. Lutzner, D. L. Nelson, R. P. MacDermott, M. L. Durm, C. K. Goldman, B. D. Meade, and T. A. Waldmann. 1976. The Sezary syndrome: a malignant proliferation of helper $\mathrm{T}$ cells. $J$. Clin. Invest. 58: 1297-1306.

6. Berger, C. L., D. Warburton, J. Raafat, P. LoGerfo, and R. L. Edelson. 1979. Cutaneous T-cell lymphoma. Neoplasm of $T$ cells with helper activity. Blood. 53: 642651 .

7. Edelson, R. L. 1980. Cutaneous T cell lymphoma: mycosis fungoides, Sezary syndrome, and other variants. $J$. Am. Acad. Dermatol. 2: 89-106.

8. Epstein, E. H., Jr., D. L. Levin, J. D. Croft, Jr., and M. A. Lutzner. 1972. Mycosis fungoides. Survival, prognostic features, response to therapy, and autopsy findings. Medicine (Baltimore). 51: 61-72.

9. Edelson, R. L. 1980 . Cutaneous T-cell lymphoma. J. Dermatol. Surg. Oncol. (New York). 6: 358-369.

10. Ritz, J., J. M. Pesando, J. Notis-McConarty, H. Lazarus, and S. F. Schlossman. 1980. A monoclonal antibody to human acute lymphoblastic leukemia antigen. Nature (Lond.). 283: 583-585.

11. Colcher, D., P. H. Hand, M. Nuti, and J. Schlom. 1981. A spectrum of monoclonal antibodies reactive with human mammary tumor cells. Proc. Natl. Acad. Sci. USA. 78: 3199-3203.

12. Imai, K., G. A. Molinaro, and S. Ferrone. 1980. Monoclonal antibodies to human melanoma-associated antigens. Transplant. Proc. 12: 380-383.

13. Magnani, J. L., M. Brockhaus, D. F. Smith, V. Ginsburg, Z. Steplewski, and H. Koprowski. 1981. A monosialoganglioside is a monoclonal antibody-defined antigen of colon carcinoma. Science (Wash., DC). 212: 55-56.

14. Kohler, G., and C. Millstein. 1975. Continuous cultures of fused cells secreting antibody of predefined specificity. Nature (Lond.). 256: 495-497.

15. Sharon, J., S. L. Morrison, and E. A. Kabat. 1980. Formation of hydridoma clones in soft agarose: Effect of $\mathrm{pH}$ and of medium. Somatic Cell Genet. 6: 435-441.

16. Hunter, W. M. 1978. Radioimmunoassay. In Handbook of Experimental Immunology. D. M. Weir, editor. Blackwell Scientific Publications, Oxford. 3rd edition. 14: 14.1-14.40.

17. Chu, A. D., and D. M. MacDonald. 1979. Identification in situ of $\mathrm{T}$. lymphocytes in dermal and epidermal infiltrates of mycosis fungoides. Brit. J. Dermatol. 100: 177-189.

18. Boyum, A. 1967. Isolation of leukocytes from human blood. Scand. J. Clin. Lab. Invest. 21 (Suppl. 97): 31-50.

19. Weiner, M. S., C. Bianco, and V. Nussenzweig. 1973. Enhanced binding of neuraminidase-treated sheep erythrocytes to human T lymphocytes. Blood. 42: 939946.

20. Marchalonis, J. J., R. E. Cone, and V. Santer. 1971. Enzymic iodination. A probe for accessible surface proteins of normal and neoplastic lymphocytes. Biochem. J. 124: 921-927.

21. Maizel, J. V., Jr. 1971. Polyacrylamide gel electrophoresis of viral proteins. Methods Virol. 5: 179-246.

22. Hays, W. L. 1973. Statistics for the social sciences. Holt, Rinehardt \& Winston, Inc., New York. 389-430.

23. Bunn, P. A., Jr., M. S. Huberman, J. Whang-Peng, G. P. Schechter, J. G. Guccion, M. J. Matthews, A. F. Gazdar, N. R. Dunnick, A. B. Fischmann, D. C. Ihde, M. H. Cohen, B. Fossieck, and J. D. Minna. 1980. Prospective staging evaluation of patients with cutaneous T-cell lymphomas. Demonstration of a high frequency of extracutaneous dissemination. Ann. Intern. Med. 93: 223-230.

24. Schecter, G. P., P. A. Bunn, A. B. Fischmann, M. J. Matthews, J. Guccion, F. Soehnlen, D. Munson, and J. D. Minna. 1979. Blood and lymph node T lymphocytes in cutaneous $\mathrm{T}$-cell lymphoma: evaluation by light $\mathrm{mi}$ croscope. Cancer Treat. Rep. 63: 571-574.

25. Edelson, R. L., C. L. Berger, J. Raafat, and D. Warburton. 1979. Karyotype studies of cutaneous T-cell lymphoma: evidence for clonal origin. J. Invest. Dermatol. 73: 548-550.

26. Braylan, R., D. Variakojis, and S. Yachnin. 1975. The Sezary lymphoid cell: abnormal surface properties and mitogen responsiveness. Br. J. Haematol. 31: 553-564.

27. Meyer, C. J. L. M., A. W. F. M. van Leeuwen, E. M. van der Loo, L. B. A. van de Putte, and W. A. van Vloten. 1977. Cerebriform (Sezary-like) mononuclear cells in healthy individuals: a morphologically distinct population of $\mathrm{T}$ cells. Relationship with mycosis fungoides and Sezary syndrome. Virchows Arch. B Cell Pathol. 25: 95104.

28. Brown, G., N. Hogg, and M. Greaves. 1975. Candidate leukemia-specific antigen in man. Nature (Lond.). 258: 454-456.

29. Mohanakumar, T., R. S. Metzgar, and D. S. Miller. 1974. Human leukemia cell antigens: serologic characterization with xenoantisera. J. Natl. Cancer Inst. 52: 14351444.

30. Edelson, R. L., J. Raafat, C. L. Berger, M. Grossman, C. Troyer, and M. Hardy. 1979. Antithymocyte globulin in the management of cutaneous T-cell lymphoma. Cancer Treat. Rep. 63: 675-680.

31. Miller, R. A., and R. Levy. 1981. Response of cutaneous T-cell lymphoma to therapy with hybridoma monoclonal antibody. Lancet. II: 226-230.

32. Miller, R. A., D. G. Maloney, J. McKillop, and R. Levy. 1981. In vivo effects of murine hybridoma monoclonal antibody in a patient with T-cell leukemia. Blood. 58: 78-86.

33. Miller, R. A., D. G. Maloney, R. Warnke, and R. Levy. 1982. Treatment of B-cell lymphoma with monoclonal anti-idiotype antibody. N. Engl. J. Med. 306: 517-522. 